JOSAR, Vol. 1 No. 1 March 2019; p-ISSN: 2502-8251; e-ISSN: 2503-1155

Copyrights@ Balitar Islamic University, Blitar-Indonesia https://ejournal.unisbablitar.ac.id/index.php/josar

\title{
POTENTIALS OF SIMPING TEMPLE SITES AS HISTORY TOURISM BASED ON LOCAL CEREMONY VALUES
}

(Case Study in Sumberjati Village, Kademangan District, Blitar Regency)

1. Fandu Dyangga Pradeta, 2. Denny Arinanda Kurnia Faculty of Social and Political Sciences, Balitar University, Blitar Jl. Majapahit No. 04, Tel (0342) 813145

Email: ${ }^{1}$ fandudyangga.p@unisbablitar.ac.id, ${ }^{2}$ dennycharo@yahoo.co.id

\begin{abstract}
The Blitar region has tourism potential that can attract visitors both from its natural attractions and historical attractions. Some tourism objects that are worthy of consideration in this area are spread evenly throughout the Blitar district. In this Kademangan area there are several interesting tourist attractions to visit such as Bukit Bunda, Bukit Bonsai, Kampung Coklat and others. In addition there are also interesting historical tours in this area, one of which is the Simping Temple Historical Site in Sumberjati Kademangan village, Blitar Regency.

The purpose of this study was to determine and understand the history of the establishment of the Simping Temple, to find out the socio-cultural conditions of the community around the Simping Temple Historical Site and to understand the potential of the historical tourism object of the Simping Temple in the Kademangan area. The object of this study was in the village area Sumberjati, Kademangan District, Blitar Regency. The subject of this research is the source of the data requested for information in accordance with the research problem formulation. This research uses a descriptive method through a qualitative approach that directly looks at the conditions and phenomena around Simping Temple. Data collection methods used used observation, interviews and documentation studies. This study explains that Simping Temple has potential tourism objects to be developed with the values of local wisdom.
\end{abstract}

Keywords: Potential, Tourism, Temple, Local Wisdom

\section{INTRODUCTION}

Indonesia is a country that has a lot of tourism potential that can be developed. One of the assets owned by this country is the potential for historical tourism that does have a meaning and value of cultural wisdom that is quite deep. Many relics from the Hindu-Buddhist kingdom are still preserved as a result of ancestral heritage. Simping Temple in the Village: Sumberjati Subdistrict: Kademangan, Blitar Regency, is one of the temples from the Hindu royal heritage which is the tomb of King Raden Wijaya (the first king of the Majapahit kingdom) that holds the title Sri Kertarajasa 
JOSAR, Vol. 1 No. 1 March 2019; p-ISSN: 2502-8251; e-ISSN: 2503-1155

Copyrights@ Balitar Islamic University, Blitar-Indonesia https://ejournal.unisbablitar.ac.id/index.php/josar

Jayawardhana. The Negarakretagam book written by Empu Praspanca said that the temple was the place where Raden Wijaya was buried around $1293-1309$ AD.

At present the Simping temple is still in the form of ruins. From the range, it is estimated that the shape of the Simping temple is slender (slime) as the shape of the East Javanese temples. Simping Temple is not possible to be restored, because too many parts of the temple are missing. Some have been reconstructed, such as the top of the temple which is placed in a corner of the temple area with a height of about two meters, while the whole building has collapsed. The current condition, which has no funds, makes this Simping temple never be reconstructed again. Finally according to references in the book Negarakertagama noted that King Hayam Wuruk had renovated this temple in 1285 Saka (1363 AD).

Seeing such conditions, it is now stopped for how to make this Simping Temple start to get more attention from the local community, historians, cultural figures and the local government. One way to get this Simping Temple site back to get attention is by understanding the local wisdom values in the Simping Temple. Bumi Nusantara is full of local wisdom civilization values that can support the formation of virtuous national character so that immediate prosperity in a society realized (Marsono, 2012: 6). Departing from the problems that have been described above, indeed from us do not understand the meaning of the events of an existing historical event. It is better to have self-introspection by studying chronologically the struggle of the nation's founders. Because with the existence of a self-reflection, we can interpret every event that occurs.

\section{RESEARCH METHODS}

The research method that will be used in research is a qualitative research method with a case study approach, with the aim to reconstruct the conceptualization model of conservation and improvement of the 


\section{JOSAR, Vol. 1 No. 1 March 2019; p-ISSN: 2502-8251; e-ISSN: 2503-1155 \\ Copyrights@ Balitar Islamic University, Blitar-Indonesia https://ejournal.unisbablitar.ac.id/index.php/josar}

Observation model is the process of taking data in research or observers looking at the research situation. This technique is used to observe closely in an effort to find and explore data through direct and in-depth observations of the subjects and objects studied (Paizaluddin \& Ermalinda, 2013: 113). Research is an effort to search for something systematically. The study was conducted on the Historic Tourism Object of Simping Temple located in the Kademangan area of Blitar Regency. The object of this study is to find out the tourism potential in the area, with the intention of reviving historical tourism objects that are less well known to the wider community. Researchers try to help to develop and preserve with the support of all parties involved. With the hope that the richness of the results of culture during the Majapahit kingdom as an educational material and our reflection to better appreciate the form of struggle of the founders of this nation. The study uses a descriptive quantitative approach with samples used in a chosen and random manner. The object of research can be stated as a social situation of research that wants to know what is happening in it. On the object of this study, researchers can observe in depth the activities (activities) of people (actors) that exist in certain places (Sugiyono, 2007: 215). The object of this research is in the village area Sumberjati, Kademangan District, Blitar Regency. The subject of this research is the research subject is the source of the data requested in accordance with the research problem. The intended source of data in the study is the subject from which the data was obtained (Suharsimi Arikunto, 2002: 107). To get the right data, an informant who has competency and in accordance with the data needs (purposive) needs to be determined. This study aims to determine the potential of simping temple tourism, its influence on the living conditions of the community in the local area, the role of the parties associated with responsibility for the simping temple, the enthusiasm of visitors who come and its influence on other tourism around the simping temple.

\section{RESULTS AND DISCUSSION}


JOSAR, Vol. 1 No. 1 March 2019; p-ISSN: 2502-8251; e-ISSN: 2503-1155

Copyrights@ Balitar Islamic University, Blitar-Indonesia https://ejournal.unisbablitar.ac.id/index.php/josar

\section{A. History of the Development of Folklore and Myth About Simping Temple Site and Social and Cultural Conditions of the Community in Sumberjati Village Area, Kademangan Blitar District}

Speech stories or folklore are often used to reconstruct the historical events of the masasilam, when supporting historical data are not found. For cases like this, the story could be a reference for historical reconstruction. However, if the supporting data from the narrative is confronted with historical data, both chronicles, manuscript types, older records, the authority of the narrative is as a complement. The story of the existence of Simping Temple in Sumberjati Village, Kademangan District, Blitar Regency certainly cannot be separated from searches carried out by important people in the Dutch East Indies colonial period in Indonesia. The existence of a century of emptiness that extends too long to civilization in the southern Blitar region makes the development of myths about the ruins of these ancient buildings gradually fade. System changes the government in each of the ruling kingdoms that followed, accompanied by the influx of new streams of belief, made the ancient building gradually begin to be abandoned. Tutur stories that develop in the community are generally limited to telling aboutlocal myths and the story of the Village Chronicle. In Sumberjati Village itself, the initial entry civilization is thought to be around the beginning of the 18th century. According to the story of the elders, residents of the region. South Blitar is mostly immigrants from Mataraman. This is reinforced by the theory. The history of the formation of the Blitar Regentschap is closely related to the Java War. According to research by Pramita Oktarina (1: 2013), the Java War that occurred between 18251830 considered as the beginning in discussing the history of the entry of civilization in southern Blitar. Dutch victory made many remnants of the Diponegoro paramilitary escaped to safe areas and one of them is Srengat and part of it spread to South Blitar region. Referring to the Dutch East Indies Colonial records in the book "Natuurkundig Tijdschrift Voor Nederlandsch Indie" published in Batavia in 1856, the first Simping 


\title{
JOSAR, Vol. 1 No. 1 March 2019; p-ISSN: 2502-8251; e-ISSN: 2503-1155 \\ Copyrights@ Balitar Islamic University, Blitar-Indonesia https://ejournal.unisbablitar.ac.id/index.php/josar
}

\begin{abstract}
Temple was rediscovered by Johannes Elias Teijsmann on 30 July 1854, then Simping Temple the origin and name are still unknown. As with other temples in Indonesia, the surrounding community calls the Simping Temple by the name Soengkoep (in long pedestal reads containment / cupping). In the Big Indonesian Dictionary cupola / cupola / cung • kup / is defined as a roofed building above the tomb astomb protector; grave house. So to clarify the naming, most temples in Indonesia whose real name is unknown, the agreement taken in the world archeology is to name the temple based on the name of the village where the temple was discovered.
\end{abstract}

Therefore the naming of the ancient building was adjusted to the name Sumberjati Village namely Tjandi Sumberdjati. After conducting research by Dutch East Indies scientists and followed by the rediscovery of Negakertagama Kakawin, a book that contains the history of the Kingdom of Mahapahit by Mpu Prapanca by J.L.A. Brandes in 1894, Tjandi Sumberdjati could be identified as one of the ancient heritage buildings in the kingdom of Macapahit called Simping. The existence of the Hari-Hara statue or the embodiment of Wisnu-Siwadi Sumberdjati Temple is strongly suspected as a place of harmony for the First King of the Mahapahit Kingdom, Kertarajasa Jayawardhana or often known as Raden Wijaya. Many myths have developed among the people regarding the existence of Simping Temple in Desa Sumberumber. Some of them believe that Simping Temple is one of the "danyangan" places. Understanding danyang itself in Javanese culture is the supreme spirit that inhabits a place called punden. Danyang or spirits themselves are believed by the people to settle in wingit places such as large trees, springs, rocks. Some people related the story that became the forerunner of the village Sumberjati. The village which was once a wilderness area, by the government.Majapahit is opened into a village which can then be inhabited by humans. For your contribution that, the community then considers the Simping Temple also as the embryo of The Owner"Sing 
JOSAR, Vol. 1 No. 1 March 2019; p-ISSN: 2502-8251; e-ISSN: 2503-1155

Copyrights@ Balitar Islamic University, Blitar-Indonesia https://ejournal.unisbablitar.ac.id/index.php/josar

Mbau rekso "Sumberjati village. The Simping Temple is considered to be the only ancient building in Sumberjati Village. In addition to being a tourist also a place that is very sacred by the surrounding community.

\section{B.Potential tourism object of the Simping Temple in the Kademangan district. Blitar}

The potential of the Simping Temple tourism object in the Kademangan area of Blitar Regency can be said to be quite promising as a vehicle for historical heritage. Many save stories left behind from time to time that continues to grow until now. Of course this needs to get appreciation and encouragement to continue to maintain and preserve one of the assets of history that is rich in stories of the past. In this case the author invites the people of the Kademangan region and in general the Blitar city community to help preserve the culture that is the pride of the Blitar city community. Judging from the profile of Simping Temple, its existence is still not well known by the wider community of Blitar. This needs to get attention for all parties to dare to explore and publish to the wider community one of them through socialization. Media that can be used to expand this information is by holding seminars, workshops or opening discussion forums related to historical themes. This Simping Temple has a pretty good potential to boost the popularity of historical relics in the Blitar city area. Some events or traditions are routinely carried out as the preservation of cultural values, customs and respect for the elders who were once part of important figures of the Majapahit kingdom.

\section{Coconut Sugar Sap Festival}

The collaboration of the Sulud Sukma Cultural Community with the East Java Arts Council succeeded in transforming the Simping Temple ruins into a monument to the rise of the Majapahit Proclamator in Blitar. Through the East Java Art Roadshow, an activity titled Getih-Getah Gulo Kelapa Simping Temple held in 2018 yesterday, successfully amazed 500 


\section{JOSAR, Vol. 1 No. 1 March 2019; p-ISSN: 2502-8251; e-ISSN: 2503-1155 \\ Copyrights@ Balitar Islamic University, Blitar-Indonesia https://ejournal.unisbablitar.ac.id/index.php/josar}

spectators and 100 invited guests who attended. This activity began with singing the song Indonesia Raya 3 Stanza, which was guided by the Tourism Ambassador of Blitar Regency, followed by a Jimbe Percussion Music performance, which illustrates the war situation between Raden Wijaya who beat back the tar-tar army back to their country and the Ngabekti ritual dance accompanied by 12 a cross-generation macapat developer who illustrates the devotion of 4 wives of Raden Wijaya in inspiring Raden Wijaya to establish and enlarge the power of the Majapahit Kingdom.

The Simping Temple holds enormous cultural and historical values, especially concerning the majapahit proclamator's ashes at this location. In the future, Blitar will make the Simping Temple the milestone of the nation's revival. Simping Temple is not just a cultural heritage building. But also as a place to explore ideas, explore inspiration, and explore knowledge about the archipelago, especially about the values of nationality, the value of diversity, and the value of mutual cooperation that began to fade, must be realized. The Coconut Sugar Getih Festival is not just a cultural art performance. This festival is the Stage of the Indonesian Multicultural Meeting. There are Javanese Culture, Chinese Culture and Interfaith Culture. Yesterday's Coconut Sugar Getih Festival yesterday, is not just a 725 majapahit celebration. More than that, the festival has been transformed as a Multicultural Stage presented by the Blitar community to Indonesia.

Cultural Kirab in the Clean Order of the Kirab Cultural Village in the context of the clean activities of Sumberjati village, Kademangan District,

Blitar Regency. This activity starts from the Sumberjati Village and Finish Village Office Yard at Simping Temple with a distance of about 1 $\mathrm{Km}$. Events like this are always carried out in order to preserve Javanese cultural traditions that have traditionally been carried out. The village cleansing program in the Kademangan area is relatively different from that carried out in other villages that are only internal in nature. However, in 
JOSAR, Vol. 1 No. 1 March 2019; p-ISSN: 2502-8251; e-ISSN: 2503-1155

Copyrights@ Balitar Islamic University, Blitar-Indonesia https://ejournal.unisbablitar.ac.id/index.php/josar

Sumberjati Kademangan Village, events like this are usually attended by Blitar city officials such as Blitar Regency DPRD members, Kapolsek, Danramil, Kademangan District Head, Elders or Pinisaters, Artists and Culturalists who are members of the LPPBN, Community Leaders and Sumberjati Village Community and surrounding. The Kirab Budaya is led by a light bud in the form of Hanoman, then followed by troops carrying red and white flags, artists and cultural figures, tumpeng mateng, tumpeng produce, Village Apparatus and Sumberjati Village Community, who wear old school clothes. Arriving at the Simping Temple, all Kirab troops surround Simping Temple area 7 times to the right, then held a Ancestor Honor Ceremony, led by Father Lukmin. Kirab Candi Simping Culture, this needs to be emulated and encouraged. This is one proof that our ancestral customs and culture are still preserved by looking at the country's own largest icon, the Simping Temple. Because Simping Temple has an extraordinary history not only nationally but also internationally, because Simping Temple is a donation from the Founder of the Majapahit Kingdom namely Raden Wijaya. This event has the aim of preserving culture and showing that Sumberjati Village has a Historical Heritage in the form of Simping Temple. Hope in the future can lift Simping Temple to be one of the selected tourist attractions in Bliltar Regency.

\section{CONCLUSION AND SUGGESTIONS}

A. Conclusion

The Simping Temple site has a fundamental meaning as a lesson for us all in understanding the Majapahit kingdom's footprint. It is expected that all parties, both local governments and local communities to concentrate on helping to preserve and preserve this historical heritage. Blitar, which is known for keeping many historical relics and other tourist destinations, can certainly support the development of the existence of this Simping Temple Site. The author hopes the Blitar city community in particular can find out the existence of this site which indeed has long 
JOSAR, Vol. 1 No. 1 March 2019; p-ISSN: 2502-8251; e-ISSN: 2503-1155

Copyrights@ Balitar Islamic University, Blitar-Indonesia https://ejournal.unisbablitar.ac.id/index.php/josar

escaped our common view. There must be an effort made especially for those who are involved as historians or other historical observers to participate in socializing the existence of this site. The potential of this Simping Temple tourism object, if it can be developed properly, will have a positive impact on other tourism objects in the Kademangan area. It is hoped that the economic growth of the local community can grow and the socio-cultural psychological condition of the local community can be established with harmony and civilization. With various efforts made in the future, hope will be created or born of local wisdom values that grow and develop from socio-cultural life that is strengthened by the ancestral traditions of the Sumberjati village area. With this historical heritage can provide profound meaning and value of wise education for future generations based on the values of local wisdom.

B. Suggestions

From the results of these conclusions, as for the advice that can be submitted by the writer is the importance of preserving historical heritage as a potential tourist attraction to be developed. This research needs to be further developed to obtain maximum results related to the development of the potential of this historical tourism object of Simping Temple. For this reason, there is a need for suggestions and input as an evaluation process so that this work can be useful for the people of Blitar in particular

\section{Acknowledgment}

We as the authors of this study would like to thank all those who have helped carry out this research and come to the final stage. We need to appreciate, especially for the Kademangan village community and community leaders and caretakers of the Simping Temple who have helped us in compiling this paper. We also thank the Balitar Islamic University for providing funding to fund this research. We hope that this research can be of benefit to us all. 
JOSAR, Vol. 1 No. 1 March 2019; p-ISSN: 2502-8251; e-ISSN: 2503-1155

Copyrights@ Balitar Islamic University, Blitar-Indonesia https://ejournal.unisbablitar.ac.id/index.php/josar

\section{REFFERENCES}

Arikunto, S. 2002. Metodologi Penelitian. Penertbit PT. Rineka Cipta. Jakarta

Arikunto, S. 2006. Metodologi Penelitian. Penertbit PT. Rineka Cipta. Jakarta

Brahmantyo, Goenadi. (2007). Perwara Sejarah. IKIP Malang : Malang

Bungin, Burhan. (2012). Analisis Data Penelitian Kualitatif. Jakarta: Raja Grafindo Persada.

CO \& Lange. 1856. "Natuurkundig Tijdschrift Voor Nederlandsch Indie" Nederlandsch Indie. Batavia. Collection Library Of The New York Botanical

Garden 1931.

Kochhar, S. 2008. Pembelajaran Sejarah. Jakarta: PT. Gramedia Widiasarana Indonesia

Kuntowijoyo. 1995. Pengantar IImu Sejarah. Yogyakarta : PT. Yayasan Bentang Budaya

Marsono, 2012. Revitalisasi Nilai-nilai Dalam Ungkapan Nusantara Guna Membangun Karakter Bangsa. Yogyakarta: Sastra Nusantara FIB UGM.

Muljadi. 2009. Kepariwisataan dan perjalanan. Jakarta: PT RajaGrafindo Persada

Nyoman S Pendit. 1994. Ilmu Pariwisata Sebuah Pengantar Perdana. Jakarta : Pt Pradnya Paramita

Paizaluddin \& Ermalinda, 2013. Penelitian Tindakan Kelas (Classroom Action Reaserch) Panduan Teoritis dan Praktis. Bandung: Alfabeta.

Sartini, 2004. Menggali kearifan local Nusantara sebagai kajian filsafat. Jurnal Filsafat

Sugiyono, 2007. Metode Penelitian Kuantitatif Kualitatif dan R\&D. Bandung: Alfabeta

Sugiyono. 2013. Metode Penelitian Kuantitatif Kualitatif dan R\&D. Bandung: Alfabeta

Sumaatmaja, 2003: IImu Pariwisata, Jakarta, Pradanya Paramita.

Peraturan Perundang- undangan

Ensiklopedi Indonesia, Departemen Pendidikan dan Kebudayaan, (Jakarta: Pakhi Pamungkas, 1997), halaman 358.

Departemen Pendidikan dan Kebudayaan, 1990. Kamus Besar Bahasa Indonesia. Jakarta: Balai Pustaka 
JOSAR, Vol. 1 No. 1 March 2019; p-ISSN: 2502-8251; e-ISSN: 2503-1155

Copyrights@ Balitar Islamic University, Blitar-Indonesia https://ejournal.unisbablitar.ac.id/index.php/josar

Arsip Pemerintahan Desa Sumberjati "Babad Dusun Ringinanom". Sumberjati,KademanganBlitar.

Journal Articles

Yunita Dwi Rahmayanti dan V. Indah Sri Pinasti, Universitas Negeri Yogyakarta. Jurnal yang berjudul " Dampak Keberadaan Objek Wisata Waduk Sermo Terhadap Perubahan Sosial Ekonomi Masyarakat Di Sremo, Kulon Progo, Daerah Istimewa Yogyakarta “.

Arfi Prasongko (2017) Universitas Nusantara PGRI Kediri. Skripsi yang berjudul "Makna Dan Nilai Budaya Pada Relief Cerita Panji Di Candi Surowono Sebagai Dasar Pengembangan Pendidikan Karakter".

Taufan Madiasworo, ST, MT (2009). Judul "Revitalisasi Nilai-Nilai Kearifan Lokal Kampung Melayu Semarang Dalam Pembangunan Berkelanjutan".

Danang Finantoko \& Abraham Nurcahyo (2015). Dalam jurnal yang berjudul " Pengaruh Candi Cetho Sebagai Obyek Wisata Sejarah Terhadap Kehidupan Sosial Ekonomi Masyarakat Desa Gumeng Kecamatan Jenawi Kabupaten Karanganyar ".

Oktarina, Paramita. 2013. Sejarah Terbentuknya Regentschap Blitar (1830-1885).

Skripsi Jurusan Pendidikan Sejarah Fakultas IImu Sosial Universitas Negeri Malan 